\title{
THE ROYAL SOCIETY OF EDINBURGH
}



\section{PROCEEDINGS}

Section B (Biological Sciences)

ISSN-0308-2113

PUBLISHED BY THE ROYAL SOCIETY OF EDINBURGH

22 GEORGE STREET, EDINBURGH, EH2 2PQ 


\title{
EDITORIAL BOARD
}

\author{
W. W. FLeTCHER
}

University of Strathclyde

W. C. Bowman

University of Strathclyde

J. MORTON BOyD

Nature Conservancy Council

R. I. CURRIE

Dunstaffinage Marine Research

Laboratory, Oban, Argyll

G. J. F. Dutron

University of Dundee

C. H. Gimingham

University of Aberdeen

J. C. Gould

Central Microbiological Laboratory, Western General Hospital, Edinburgh

K. E. Halnan

Hammersmith Hospital, London

J. HAWTHORN

University of Strathclyde

R. M. S. SMELLIE

General Secretary

Royal Society of Edinburgh
D. M. Henderson

Royal Botanic Garden, Edinburgh

A. M. Macleod

Edinburgh

J. D. Matthews

University of Aberdeen

R. J. ROBERTS

University of Stirling

F. W. ROBERTSON

University of Aberdeen

J. A. F. Rook

Agricultural Research Council, London

J. E. SMITH

University of Strathclyde

A. Watson

Institute of Terrestrial Ecology,

Blackhall, Banchory

W. H. RUTHERFORD

Executive Secretary

Royal Society of Edinburgh 


\section{PROCEEDINGS}

OF THE

ROYAL SOCIETY OF EDINBURGH 


\section{PROCEEDINGS}

\section{OF \\ THE ROYAL SOCIETY OF EDINBURGH}

Section B (Biological Sciences)

VOL. 80

1981

PUBLISHED BY

THE ROYAL SOCIETY OF EDINBURGH

22 GEORGE STREET

EDINBURGH EH2 2PQ

1981 
Printed by Latimer Trend \& Company Ltd, Plymouth, England 


\section{Contents}

\section{Introduction}

The marine environment of Sullom Voe and the implication of oil developments

by T. H. Pearson and S. O. STanley

\section{Social and political background to the environmental studies}

Shetland and the building of the Sullom Voe crude oil terminal by M. Fenwick

\section{Pollution and monitoring strategy}

The SOTEAG programme of monitoring in Sullom Voe by P. Foxton

Anti-oil pollution strategy in Sullom Voe-environmental considerations by W. J. SyRatT and M. G. Richardson

The physical and chemical environment

Oceanographic observations in Sullom Voe, Shetland in the period 1974-78 by H. D. DOOLEY

Tidal currents in Yell Sound and the outer regions of Sullom Voe

by D. L. Blackman, J. GrafF and J. M. Vassie

Some aspects of the sediment chemistry of Sullom Voe, Shetland

by S. O. Stanley, B. E. Grantham, J. W. Leftley and Mrs N. Robertson

Some observations on the distribution of heavy metals in Sullom Voe

by P. COACKLEY, D. H. BACHE and P. G. SMITH

Analysis of hydrocarbons in sediments as indicators of pollution

by A. G. Douglas, P. B. Hall, B. Bowler and P. F. V. Williams

Origin and fate of hydrocarbons in Sullom Voe

by J. M. Davies, R. Johnston, K. J. Whittle and P. R. Mackie

\section{Studies on Shetland vertebrate populations}

Monitoring seabirds in Shetland

by M. G. Richardson, G. M. Dunnet and P. K. Kinnear

Seals in Shetland waters

by SHEILA S. ANDERSON 
The biology of Sullom Voe

The salt marshes of Sullom Voe

by D. H. DALBY

The soft shore environment of Sullom Voe and the north mainland of Shetland 203 by A. M. JONES and Y. M. JONES

The rocky shore ecology of Sullom Voe

by KeITH HISCOCK

The benthic ecology of Sullom Voe

by T. H. Pearson and A. Eleftheriou

The macrobenthos of Sullom Voe by J. M. ADDY

The physical and biochemical condition of Modiolus modiolus $(\mathrm{L})$ in selected Shetland voes

by С. А. COMELY

Measurement of the responses of mussels to environmental stress and pollution in Sullom Voe: a base-line study

by J. Widdows, B. L. Payne, P. Donkin, D. R. Livingstone, D. M. Lowe, M. N. MOORE and P. N. SALKELD

Monitoring studies at other oil terminals

The Flotta Terminal and its effects on the marine environment by C. S. JoHNSTON

Problems in ecological monitoring in Port Valdez, Alaska

by E. B. Cowell, and D. C. MonK 